Historia Slavorum Occidentis

2020, nr 1 (24)

ISSN 2084-1213

DOI: $10.15804 /$ hso200109

\author{
Marcin Danielewski (Poznań)
}

ORCID 0000-0003-3897-2617

\title{
J. Panek, O. Tüma et alli, $A$ History of the Czech Lands, Prague 2018, ss. 730
}

W 2018 r. Wydawnictwo Uniwersytetu Karola w Pradze (Karolinum Press) wydało książkę pt. A History of the Czech Lands. Jest to drugie wydanie tej monumentalnej rozprawy, której autorami jest dwudziestu uczonych na co dzień zajmujących się problematyką czeską na przestrzeni dziejów. Pierwsze anglojęzyczne wydanie książki pochodziło z 2009 r. , a czeska wersja opracowania pojawiła się na rynku księgarskim już w $2008 \mathrm{r}$. W związku z nowym wydaniem A History of the Czech Lands wypada przyjrzeć się tej rozprawie i ocenić jej wartość oraz potencjalną przydatność dla polskiego czytelnika.

Recenzowana książka liczy 730 stron i została podzielona na dwadzieścia trzy rozdziały, których autorami jest dwudziestu naukowców. W tym dwóch z nich Jaroslav Pánek i Oldřich Tůma nadzorowało również redakcję opracowania. Rozprawa została poprzedzona kilkustronicowym wstępem do jej nowej edycji (s. 17-19), a zakończona licznymi dodatkami w postaci: wykazu zastosowanych w pracy skrótów (s. 703-704), spisu ilustracji, tabel i map (s. 705-710), wykazu przedstawicieli państwa czeskiego (s. 711-713), spisu często używanych nazw geograficznych (s. 714-715), map, indeksu osobowego (s. 719-729). Wspominałem już wyżej, że rozprawę zaopatrzono w liczny materiał ilustracyjny, który pozytywnie wpływa na odbiór książki, aczkolwiek szkoda, że wyłącznie mapy zawarte na końcu opracowania zostały wydrukowane w kolorze. Natomiast pozostałe ryciny znajdujące się przy kolejnych rozdziałach wydrukowano w czerni i bieli, co w przypadku prezentacji 
archeologicznych, zabytków (np. s. 59, 68, 109), architektury (np. s. 77, 202), map (np. s. 34), ikonografii (np. s. 40, 43, 79, 88, 101, 112, 127, 135, 162, 167, 171, 175, 192, 197, 210-211), dokumentów (np. s. 145, 200) nieco psuje odbiór szaty graficznej. Szkoda, że nie udało się całości materiału ilustracyjnego zaprezentować w kolorze, choć domyślam się, że znaczenie mogły mieć tutaj uwarunkowania finansowe.

Omawiana praca cechuje się w przeważającej części układem chronologicznym, choć akurat pierwszy rozdział autorstwa Evy Semotanovej pt. „Territorial Development and the Transformation of Landscape" (s. 23-53) ma charakter przekrojowy, a uczona starała się w nim zaprezentować rozwój terytorialny ziem czeskich na przestrzeni dziejów od wczesnych wieków naszej ery po XXI w. Wszystkie artykuły są skonstruowane w podobny sposób, a więc bez aparatu krytycznego w postaci przypisów, a z prezentacją po każdym rozdziale bibliografii adekwatnej do rozważań zawartych w rozdziale. W pracy widoczna jest jednak znacząca dysproporcja względem miejsca przeznaczonego na omówienie kolejnych okresów czasowych. Najwięcej uwagi poświecono zagadnieniom związanym z problematyką czeską w XX i XXI w., aż dziesięć pełnych rozdziałów dotyczy tej problematyki (rozdziały od XIV do XXIII). Podczas gdy tematyka ziem czeskich w XIX stuleciu zajęła zaledwie trzy rozdziały (od XI do XIII), a np. okres pradziejowy niecały jeden (rozdział I). Ta dysproporcja wynika z liczby źródeł, którymi poszczególni naukowcy dysponowali względem poszczególnych przedziałów chronologicznych, choć wydaje się, że jednak ziemiom czeskim w pradziejach czy nowożytności warto było poświęcić nieco więcej miejsca.

Wspomniałem już powyżej, że jeden rozdział - „Prehistory and Beginnings of Slavic Settlement (to the $8^{\text {th }}$ Century)", którego autorem jest Dušan Třeštík, został poświęcony okresowi pradziejowemu i początkom osadnictwa słowiańskiego (s. 55-63). W prezentowanej książce historia czeskich ziem została omówiona od młodszej epoki kamienia, a więc neolitu (s. 57), autor tej części pracy nie odniósł się do starszych okresów pradziejowych mezolitu i paleolitu, aczkolwiek już wówczas na tych obszarach, które obecnie określa się mianem ziem czeskich, egzystował człowiek. Wydaje się, że mimo wszystko szkoda, iż więcej miejsca nie poświecono zagadnieniom związanym z najstarszymi społecznościami pradziejowymi, które funkcjonowały na omawianym obszarze. Większą uwagę należałoby też poświecić Celtom, których osadnictwo miało duży wpływ na rozwój tej części Europy Środkowej. Interesujący wydaje się także problem obecności Markomanów na tym obszarze i ówczesnych wpływów Cesarstwa Rzymskiego. Uważam, że te interesujące tematy mogły i powinny być jednak w tak ważnej monografii szerzej przedstawione. 
Zdecydowanie bardziej wyczerpująco omówiono problem ziem czeskich w okresie wczesnego średniowiecza. Zagadnienia te zostały zaprezentowane na łamach pięciu rozdziałów (III-VII), aczkolwiek już wspominany wcześniej tekst Dušana Třeštíka odnosił się do najstarszego osadnictwa słowiańskiego (s. 61-63). Dzieje Wielkich Moraw oraz władztwa czeskiego do 1306 r., a więc do wygaśnięcia dynastii Przemyślidów omówili D. Třeštík - „Great Moravia and the Beginnings of the State ( $9^{\text {th }}$ and $10^{\text {th }}$ Centuries)" (s. 65-84) - i ponownie wyżej wymieniony z Josefem Žemličką - „The Czech State in the Era of Přemyslid Princes and Kings (from the Beginning of the $11^{\text {th }}$ Century to 1306)" (s. 85-122). Okres panowania Luksemburgów w Czechach do pierwszej defenestracji praskiej przedstawił Miloslav Polívka - „The Expansion of the Czech State during the Era of the Luxemburgs (1306-1419)" (s. 123-156), a problem rewolucji husyckiej zaprezentował František Šmahel - „The Hussite Revolution (1419-1471)” (s. 157-183). Wreszcie już do czasów styku średniowiecza i nowożytności odnosi się tekst pt. „The Bohemian Crownlands under the Jagiellons (1471-1526)” (s. 185-205), którego autorem jest Jaroslav Boubín.

Okres nowożytności został zaprezentowany na kartach trzech rozdziałów. Pierwszy z nich, omawiający ziemie czeskie pod panowaniem Habsburgów od $1526 \mathrm{r}$. do klęski Czechów w bitwie pod Białą Górą - „The Czech Estates in the Habsburg Monarchy (1526-1620)” (s. 207-252) - jest autorstwa J. Pánka. Autor kolejnego rozdziału Jiří Mikulec zamknął swoje rozważania w okresie zamykającym się miedzy bitwą pod Białą Górą w 1620 r. a końcem panowania Karola VI Habsburga - „Baroque Absolutism (1620-1740)” (s. 253-285). Wreszcie ostatni rozdział dotyczący nowożytności odnosi się do przedziału czasowego między początkiem panowania Marii Teresy a końcem rządów Leopolda II Habsburga - „Enlightened Absolutism and the Birth of a Modern State (1740-1792)” (s. 287-309), a jego autorką jest Martina Ondo Grečenková.

Kolejne trzy rozdziały zostały poświęcone omówieniu ziem czeskich w latach 1792-1914. Pierwszy z nich - „The Birth of the Modern Czech Nation (1792-1848)” (s. 311-342), którego autorami są Jan Hájek i Milan Hlavačka stał się pretekstem do przedstawienia problemu narodzin czeskiego narodu. Następna z części rozprawy - „Czechs during the Revolution and Neo-absolutism (1848-1860)” (s. 343-362) - posłużyła, aby zaprezentować dalszy rozwój czeskich idei narodowych i ich miejsca w neo-absolutystycznej monarchii Habsburgów. Autorem tego tekstu jest M. Hlavačka. Wreszcie okres między 1860 r., a więc końcem epoki absolutyzmu w Czechach, a 1914 r., czyli wybuchem pierwszej wojny światowej, został 
omówiony w rozdziale pt. „The Definition of Czech National Society during the Period of Liberalism and Nationalism (1860-1914)" (s. 363-414). Autorami tego tekstu są Pavel Cibulka, Jan Hájek, Martin Kučera.

Jak już wyżej wspomniałem największa część recenzowanej książki została poświęcona problematyce ziem czeskich w XX w. Okres pierwszej wojny światowej w odniesieniu do Czech - „The Czech Lands during the First World War (1914-1918)” (s. 415-433) - przedstawił Josef Harna. Ten sam uczony omówił zagadnienia związane z funkcjonowaniem pierwszej Republiki Czechosłowackiej - „First Czechoslovak Republic (1918-1938)” (s. 435-477). Kolejny rozdział pt. „Czechoslovakia in the years after the Munich Agreement and in the Second World War (1938-1945)" (s. 479-508) autorstwa Jana Gebharta odnosi się do problematyki ziem czeskich w obliczu drugiej wojny światowej.

Okres powojenny w odniesieniu do Czech i do momentu upadku komunizmu przedstawiono na kartach pięciu rozdziałów. Pierwszy z nich autorstwa Jiř́ego Kociana dotyczy wczesnych lat powojennych - „Czechoslovakia between Two Totalitarian Systems (1945-1948)” (s. 509-339). W kolejnym rozdziale Jiř́ Pernes omówił okres od praskiego zamachu stanu w lutym 1948 r., po 1958 r. - „The Establishment and First Crisis of the Communist Regime in Czechoslovakia (1948-1958)" (s. 541-572). Ten sam uczony jest autorem także kolejnej części pracy - „Communist Czechoslovakia on a Journey from a Consolidation of Totalitarianism towards a Liberalization of the Regime (1959-1967)” (s. 573-590). Wreszcie O. Tůma przygotował kolejne dwa rozdziały: „The Half-Life: the Communist Regime's Greatest Crisis (1967-1971)” (s. 591-622) oraz „The Second Consolidation of the Communist Regime and the Descent into Collapse (1972-1989)” (s. 623-643), w których omówiono powolny kryzys i upadek komunizmu.

Dzieje demokratycznych Czech po 1989 r. zostały przedstawione na kartach dwóch rozdziałów. Krótszy okres czasu miedzy 1989 a 1993 r. zaprezentował Jiř́ Suk w rozdziale pt. „Czechoslovakia's Return to Democracy (1989-1992)” (s. 645-677). Natomiast funkcjonowanie Republiki Czech od 1993 r. aż do momentu jej przystąpienia do Unii Europejskiej 1 V 2004 r. - „Czech Republic 1993-2004” (s. 679-702) - omówił Tomáš Zahradníček.

Konstrukcję książki, mimo pewnych uwag względem np. nierównego podziału objętości tekstu przeznaczonego na omówienie danych zagadnień, należy uznać za poprawną. Pewnym mankamentem pracy jest fakt, że bibliografia zamieszczona po poszczególnych rozdziałach została tylko w przypadku części tekstów uzupełniona o opracowania wydane po 2009 r. (np. s. 51-53, 122, 154-156, 182-183, 203, 
$248-252,677)$. Niektóre zaś z prezentowanych bibliografii zamykają się na latach 2008-2009 r. (np. s. 63, 82-84, 590) i szkoda, że jednak nie podjęto się trudu ich uzupełniania.

Podsumowując powyższe rozważania należy stwierdzić, że książka A History of the Czech Lands i jej drugie wydanie mimo pewnych mankamentów jest pozycją wartą uwagi. Szczególnie należy docenić fakt, że dzieje czeskich ziem zostały opublikowane w języku angielskim, co zwiększa grono potencjalnych czytelników zainteresowanych przeszłością Czech, a na co dzień nie władających językiem czeskim. Jednocześnie popularno-naukowy charakter opracowania, pozbawionego przypisów, a z zawartą na końcu każdego rozdziału bibliografią powoduje, że książka jest bardziej przystępna dla odbiorcy, który nie zajmuje się zawodowo historią czy archeologią. Uważam, że mimo upłynięcia już dekady od pierwszego anglojęzycznego wydania $A$ History of the Czech Lands, treści w niej zawarte są nadal w dużej mierze aktualne. Dobrze więc, że rozprawa ponownie trafiła do księgarń, bo można mieć nadzieję, że spopularyzuje ona historię Czech i znajdzie czytelników również w Polsce.

Dr Marcin Danielewski

Wydział Archeologii

Uniwersytet im. Adama Mickiewicza w Poznaniu

ul. Uniwersytetu Poznańskiego 7

61-614 Poznań

e-mail:m_danielewski@tlen.pl

Nadesłany 30 VII 2019

Zaakceptowany 14 VIII 2019 